\title{
Grain yield of dual-purpose wheat cultivars as affected by nitrogen and cuttings
}

\author{
Marcel Hastenpflug ( $\left.{ }^{1}\right)$; Thomas Newton Martin $\left(2^{*}\right)$; João Alfredo Braida (3); Deivid Kelli Barbosa $\left({ }^{4}\right)$; \\ Renice Paula Zielinski ( $\left.{ }^{4}\right)$; Rosana Refatti $\left({ }^{4}\right)$ \\ (') Instituto Federal de Educação, Ciência e Tecnologia de Mato Grosso do Sul (IFMS), 79900-000 Ponta Porã (MS). Brasil. \\ (2) Departamento de Fitotecnia, Universidade Federal de Santa Maria (UFSM), 97105-900 Santa Maria (RS), Brasil. \\ (3) Universidade Tecnológica Federal do Paraná, Campus Pato Branco, Via do Conhecimento, km 01, 85501-970 Pato Branco (PR), \\ Brasil. \\ (4) Universidade Tecnológica Federal do Paraná, Campus Dois Vizinhos, Estrada para Boa Esperança, km 04, 85660-000 Dois \\ Vizinhos (PR), Brasil. \\ (*) Corresponding author: martin.ufsm@gmail.com
}

Received: February 10, 2011; Accepted: August 26, 2011

\begin{abstract}
The aim of this work was to evaluate the effect of nitrogen fertilization and aerial part cuts on yield components, grain yield and quality of the grains for dual-purpose wheat cultivars. The experiment was carried out between May and November 2007 and the experimental design was randomized complete blocks with three replications. The main causes of variation were dual-purpose wheat cultivars (BRS Figueira, BRS Umbu, BRS Guatambu and BRS Tarumã), nitrogen doses (0, 45, 90, 135 and $180 \mathrm{~kg} \mathrm{ha}^{-1}$ ) and cut systems. Each plot was subdivided by cut management (without cut, one cut and two cuts). Spike mass, number of spikelets per spike, number of grains per spikelet, grain yield and hectoliter weight were evaluated. Nitrogen fertilization did not affect the performance of wheat genotypes, but there was interaction between the management systems and the cultivars. The shorter-cycle cultivars (Figueira and Umbu) presented greater grain yield than the others when they were not cut. As quality and yield fell when Figueira and Umbu were cut, the later cultivars (Tarumã and Guatambu) are more adapted to cut (grazing). The lack of an effect from nitrogen dose and application strategy on the variables studied was influenced by the ecological conditions prevailing during the experimental period.
\end{abstract}

Key words: Triticum aestivum, winter cereal, crop-livestock integration.

\section{Trigo duplo propósito submetido a regimes de corte: produção de grãos}

\section{Resumo}

O objetivo deste trabalho foi avaliar o efeito de adubação nitrogenada e cortes da parte aérea sobre os componentes do rendimento, rendimento de grãos e qualidade dos grãos de cultivares de trigo duplo propósito. O experimento foi realizado na Universidade Tecnológica Federal do Paraná, campus Dois Vizinhos, entre maio e novembro de 2007. O delineamento experimental foi o de blocos ao acaso com três repetições. Os tratamentos foram distribuídos em fatorial, cujos fatores principais eram as cultivares de trigo duplo propósito (BRS Figueira, BRS Umbu, BRS Guatambu e BRS Tarumã), as doses (e manejo da aplicação) de nitrogênio (0, 45, 90, 135 e $\left.180 \mathrm{~kg} \mathrm{ha}^{-1}\right)$ e os regimes de corte. As parcelas foram subdivididas conforme os manejos (sem corte, um corte e dois cortes). As variáveis avaliadas foram: massa da espiga, número de espiguetas por espiga, número de grãos por espigueta, rendimento de grãos e peso do hectolitro. A adubação nitrogenada não alterou o desempenho dos genótipos de trigo, porém houve interação entre os manejos e as cultivares. As cultivares de ciclo mais curto (Figueira e Umbu) porporcionam maior rendimento de grãos que as demais quando não submetidas ao corte, porém têm sua qualidade e o rendimento reduzidos quando foram cortadas, demonstrando que as cultivares tardias (Tarumã e Guatambu) são mais adaptadas ao corte (pastejo). A falta de efeito da dose e do manejo de aplicação do nitrogênio nas variáveis avaliadas foi influenciada pelas condições edafoclimáticas reinantes durante o desenvolvimento da pesquisa.

Palavras-chave: Triticum aestivum, cereais de inverno, integração lavoura-pecuária. 


\section{INTRODUCTION}

The production of dual-purpose wheat requires long vegetative periods, forage yield capacity and short reproductive periods to maintain production stability in relation to industrial output and quality of grains after the grazing cycle (WENDT et al., 2006). In this way, the use of dual-purpose wheat demands different nutrient levels when compared to grain yield alone. In the dual-purpose system, the plant should initially feature extensive green mass production to be allocated for feeding animals; afterwards, it should produce new leaf area to guarantee the required photoassimilate production for grain yield. Accordingly, grain yield will be strongly affected by plants' capacity to regenerate its aerial part, since under excessive defoliation conditions, carbohydrate reserves will initially be used for rapid formation of the leaf area (VAntini et al., 2005).

Nitrogen uptake by wheat plants varies throughout its growth cycle. In general, the absorbed amount increases progressively during the vegetative growth period and reaches its peak during the reproductive stage, before falling in the grain-filling phase (CREGAN and Berkum, 1984). On average, between 30 and $60 \mathrm{~kg} \mathrm{ha}^{-1}$ of nitrogen is used exclusively for grain wheat crops, with the smallest doses recommended for taller cultivars and/or high-fertility soils. However, some crops may require up to $120 \mathrm{~kg} \mathrm{ha}^{-1}$ of $\mathrm{N}$ (Freitas et al., 1994). Wheat grain yield can be changed by nitrogen fertilization, as function of fertilization rate and period, what can change the production components, like number of grains per spike, number of spikes per area and grain mass (BRedeMeier and Mundstock, 2001).

According to Scheffer-Basso et al. (2001), cutting plant's aerial parts tends to reduce grain yield in winter cereals, as function of leaf area limitations and tiller senescence during reproduction phase. However, DeL Duca et al. (1999) indicate that the cuts do not cause any greater harm to the chemical composition of winter cereal grains.

Cuts and fertilization may also affect the yield components, such as spike weight, number of spikelets per spike and number of grains per spike, thereby affecting grain yield (BorTolini et al., 2004). These components are closely linked to cereal yield and quality, and when adversely affected they can hinder production by reducing desirable qualitative characteristics of the product. In wheat for dual purposes, cuts and fertilization can reduce hectoliter weight of grains (KoLCHINSKI and SCHUCH, 2004), making them unfeasible for use in flour production.

In this context, the aim of this work was to assess the effects of cutting aerial parts and nitrogen fertilization in grain yield and its components of dual-purpose wheat crops.

\section{MATERIAL AND METHODS}

The experiment was carried out between May and November 2007. The experimental area is located in a physiographic region called Terceiro Planalto Paranaense $\left(25^{\circ} 44^{\prime} \mathrm{S} ; 53^{\circ} 04^{\prime \prime} \mathrm{W}\right.$, with an average altitude of $\left.520 \mathrm{~m}\right)$. The climate is humid subtropical mesothermic (Cfa) according to Köppen's classification (МАACK, 1968) and the soil classified as "Nitossolo Vermelho Distroférrico" (BHERING and SANTOS, 2008) and Oxisol (USDA, 2003). The results of chemical analysis of soil at a depth of 0 to $20 \mathrm{~cm}$ indicate that the soil has $40.2 \mathrm{~g} \mathrm{dm}^{-3}$ of organic matter, 52.1 $\mathrm{mg} \mathrm{dm}{ }^{-3}$ of phosphorus, $216.1 \mathrm{mg} \mathrm{dm}^{-3}$ of potassium, $11.4 \mathrm{mg} \mathrm{dm}^{-3}$ of copper, $55.6 \mathrm{mg} \mathrm{dm}^{-3}$ of iron, $11.5 \mathrm{mg}$ $\mathrm{dm}^{-3}$ of zinc and $213.3 \mathrm{mg} \mathrm{dm}^{-3}$ of manganese. Hydrogen potential $(\mathrm{pH})$ was 5.6, SMP index of $6.3, \mathrm{Al}^{+3}$ null, $\mathrm{H}+\mathrm{Al}$ of $3.97 \mathrm{cmol} \mathrm{dm}^{-3}, 6.1 \mathrm{cmol} \mathrm{dm}^{-3}$ of calcium, $3.6 \mathrm{cmol} \mathrm{dm}^{-3}$ of magnesium, Cations saturation (V) of $71.4 \%$ and the $\mathrm{Al}$ saturation of $0.0 \%$.

A randomized block design was used for the experiment, with seeding in rows and three replications. Plots of $3.4 \mathrm{~m}^{2}$ were used, featuring 17 rows of $9 \mathrm{~m}$ length, spaced $0.20 \mathrm{~m}$ apart. Each subplot was $3 \mathrm{~m}$ long, with the same width. Treatments formed a $4^{5}$ factorial, in which cultivars and nitrogen doses were the main factors. The wheat cultivars used were produced by EMBRAPA for dual purpose, as follows: BRS Figueira, BRS Guatambu, BRS Tarumã and BRS Umbu. The nitrogen $(\mathrm{N})$ doses applied were $0,45,90,135$ and $180 \mathrm{~kg} \mathrm{ha}^{-1}$ (the nitrogen application coverage was divided by the number of cuts, applying to the same quantities after each cut, or the total amount at tillage). The main plots (cultivars $\mathrm{x} \mathrm{N}$ doses) were subdivided into three different systems: no-cut (SC), one-cut (1C) and two-cuts (2C), comprising 180 experimental units. Wheat was grown under no-tillage, with row fertilization, using $100 \mathrm{~kg} \mathrm{ha}^{-1}$ of NPK 7-30-20, and cover fertilization by spraying potassium chloride $(\mathrm{KCl})$ with a dosage of $45 \mathrm{~kg} \mathrm{ha}^{-1}$ of $\mathrm{K} 40$ days after emergence (before rain).

Seeding density was 400 viable seeds per square meter. Nitrogen fertilization was distributed according to the cutting regime. In the subplot where there was no cut, the full dose was applied in a single application, at the start of tillering after 17 days of emergence. In the one-cut subplots, the dose was split in two times, during tillering and immediately after cutting. For the two-cut subplot, there were three applications: at tillering and after each of the two cuts. Chemical control of the crop was carried out in a single preventive application of insecticide $\left(0.04 \mathrm{~L} \mathrm{ha}^{-1}\right.$ of lambda-cialotrina + tiametoxam) and triazol-based fungicide $\left(0.75 \mathrm{~L} \mathrm{ha}^{-1}\right)$, using a volume of 200 liters of spray mix per hectare.

Cuts were carried out when the crop reached an average height of $0.3 \mathrm{~m}$, both in the first and second cuts, occurring at 60 and 85 days after emergence (DAE) 
respectively. Cut height was performed at $0.08 \mathrm{~m}$, preserving the structure responsible for plant growth. Cuts were performed with a lawn-mower, adapted to the desired cutting height.

The crop was managed until the end of the reproductive cycle, when grains reached harvest maturity, according to cultivars and management cuts, when $15 \mathrm{spi}$ kes per subplot were randomly collected for analysis of yield components. The spikes were cut and, weighed on a precision scale, in order to obtain an average spike mass. Following this, the spikelets were manually detached one by one from all 15 spikes to obtain the average number of spikelets per spike. Finally, the grains were removed from the spikelets to calculate average numbers of grains per spikelet.

After spike sampling, each of the subplots was manually harvested with the aid of a sickle, cutting all plants of the useful area, what represented an effective area of $4 \mathrm{~m}^{2}$ $(2 \mathrm{~m} \times 2 \mathrm{~m})$. Plants were conditioned in plastic bags and later threshed in a cereal blender, then the total plot grain yield was weighed. Sample humidity was then measured using a universal humidity determiner, with values converted to $13 \%$. The hectoliter weight $(\mathrm{PH})$ was verified using the methodology described in the Seed Analysis Rules of the Ministry of Agriculture (BRAsIL, 1992).

The data were submitted to the F test and the averages were compared using the Duncan test at 5\% probability level. The data were analyzed with Soc-NTIA software (EMBrapa, 1997).

\section{RESULTS AND DISCUSSION}

In this study, the crop developed without the interference of pests, diseases or weeds. The cycle of cultivars ranged from
168 to 196 days (Table 1) and the rainfall and temperature were low at times of nitrogen application (Figure 1). After some cuts and nitrogen application occurred a period of water deficit, compromising the crop answer to nitrogen rates. Thus, different rates led to no significant changes in performance of the cultivars (Figure 1).

The variance analysis of the data obtained for assessed yield components such as spike mass, number of spikelets per spike and number of grains per spikelet showed that for all variables there was a significant relationship between cultivars and cut management. However, no significant effect was caused by the different nitrogen doses applied and the management of $\mathrm{N}$ application.

Yield components are agronomic plant parameters that are used to identify grain yield-related mechanisms affected by external factors during plant development, such as the cuts and fertilizations carried out in this study. In this case, these parameters were not altered by nitrogen fertilization, being a probable consequence of the combination of two factors: a) the soil had high levels of organic matter in its upper layers; and b) the water deficit during the crop cycle was more limiting than possible nutritional deficiencies.

For the spike mass (ME), no significant difference between cultivars was observed for the no-cut (SC) and one-

Table 1. Cycle of wheat crop in days for four dual-purpose wheat cultivars subjected to different cutting managements. Dois Vizinhos (PR), 2008

\begin{tabular}{lccc|}
\hline \multirow{2}{*}{ CULTIVAR } & \multicolumn{3}{c|}{ Management system } \\
\cline { 2 - 4 } & SC & $\mathbf{1 C}$ & 2C \\
\hline BRS Figueira & 168 & 175 & 196 \\
BRS Guatambu & 189 & 189 & 196 \\
BRS Tarumã & 196 & 196 & 196 \\
BRS Umbu & 175 & 175 & 196 \\
\hline
\end{tabular}

SC: no-cut; 1C: one-cut; 2C: two-cuts

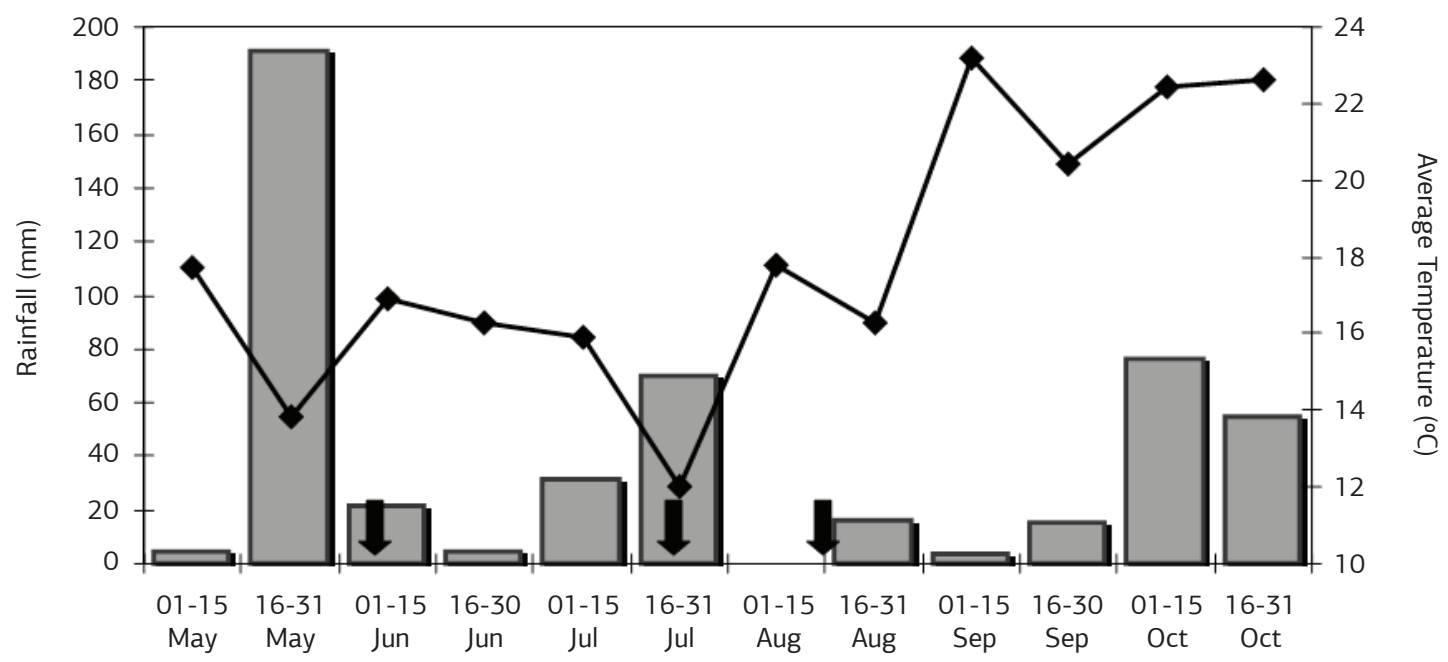

Figure 1. Meteorological data for the experimental period: rainfall $(\mathrm{mm})$ columns, and mean temperature $\left({ }^{\circ} \mathrm{C}\right)$, the lines for the fortnights of the months from May to October 2007. The arrows represent the dates of nitrogen application: 06/05, 07/20 and 08/15/2007. 
cut (1C) management regimes (Table 2). However, BRS Guatambu presented higher ME than the other cultivars in the two-cut regime (2C), with similar results for BRS Tarumá. For all cultivars, cuts resulted in low spike mass, although this reduction was sharper in the BRS Umbu cultivars $(78 \%$ and $62 \%$ reduction, respectively, for $1 \mathrm{C}$ and $2 \mathrm{C}$ in relation to SC) than in the BRS Guatambu cultivars $(5 \%$ and $28 \%$ reduction, respectively, for $1 \mathrm{C}$ and $2 \mathrm{C}$ in relation to no-cut management). When the apical meristem is cut off, the appearance of secondary tillers is induced (HENDRICKson et al., 2005) and plants produce smaller spikes with fewer grains. As a consequence, spike mass and yield are negatively affected (McRAE, 2003), as verified in this experiment and similarly observed in a study by Bortolini et al. (2004).

With regard to the number of spikelets per spike (NE) in the SC and $1 \mathrm{C}$ regimes, BRS Guatambu exhibited greater NE than the other cultivars, which did not differ among themselves. BRS Umbu showed a greater NE decrease, with a value smaller than that observed in BRS Tarumâ, but similar to BRS Figueira. BRS Figueira and BRS Umbu showed a sharper decline in NE, mainly when comparing plots submitted to $2 \mathrm{C}$ management to no-cut plots.

As for the number of grains per spikelet (NG) in SC management, semi-late cultivars (BRS Umbu and BRS Figueira) showed the higher values of NG than BRS Tarumã and BRS Guatambu, indicating more fertile spikelets. In both cut regimes, BRS Guatambu presented smaller NG than the others, which shows that although this cultivar has more spikelets, they have fewer grains. In terms of the effects of cuts on the cultivars, BRS Guatambu did not show significant alterations; BRS Tarumã had a significant fall when submitted to 2C; and BRS Figueira and BRS Umbu presented a significant decrease in both cut regimes.

In general, cultivars were adversely affected by cuts of the aerial part in at least one of their yield components: BRS Guatambu had reduction in spike mass; BRS Tarumã showed a reduction in ME and NG; and BRS Umbu and BRS Figueira presented significant reduction in the three components assessed. This differential response can be explained by the phenology and morphological traits of the cultivars. BRS Guatambu and BRS Tarumã are regarded as late-early, as they feature a long vegetative phase and a short reproductive period, which results in a longer cycle. BRS Figueira and BRS Umbu, which are considered semi-late cultivars, behave similarly to conventional cultivars, featuring a shorter cycle than the other ones, despite being adapted for dual purpose. The first two (Guatambu and BRS Tarumã) are also shorter in height (less susceptible to lodging), having greater capacity for tiller production (WENDT et al., 2006; FonTANeLI, 2007).

In this study, it was observed that the crop cycle ranged from 168 (semi-late cultivars under SC regime) to 196 days (under 2C regime), depending on the cultivars and type of regime used. However, these differences in plant cycle did not exist in plots featuring two cuts. Wheat displays a high
Table 2. Grain yield (13\% of humidity), yield components and quality components resulting from different cut regimes and dualpurpose wheat cultivars, in 2008

\begin{tabular}{|c|c|c|c|}
\hline \multirow{2}{*}{ Cultivar } & No cut & One cut & Two cuts \\
\hline & \multicolumn{3}{|c|}{ Spike mass (g) } \\
\hline BRS Figueira & $0.804 a A^{*}$ & $0.596 \mathrm{aB}$ & $0.377 \mathrm{bc}$ \\
\hline BRS Umbu & $0.981 \mathrm{aA}$ & $0.216 \mathrm{aB}$ & $0.377 \mathrm{bC}$ \\
\hline BRS Guatambu & $0.911 \mathrm{aA}$ & $0.863 \mathrm{aA}$ & $0.652 \mathrm{aB}$ \\
\hline BRS Tarumã & $0.760 \mathrm{aA}$ & 0.709 aAB & $0.536 \mathrm{abB}$ \\
\hline Average & 0.864 & 0.596 & 0.4855 \\
\hline \multirow[t]{2}{*}{ CV (\%) } & & 19.59 & \\
\hline & \multicolumn{3}{|c|}{ Number of spikelets per spike (units) } \\
\hline BRS Figueira & $12.41 \mathrm{bA}$ & 11.42 bAB & $9.93 \mathrm{bcB}$ \\
\hline BRS Umbu & $13.34 \mathrm{bA}$ & $11.55 \mathrm{bA}$ & $9.01 \mathrm{cB}$ \\
\hline BRS Guatambu & $15.44 \mathrm{aA}$ & $14.55 \mathrm{aA}$ & $13.24 \mathrm{aA}$ \\
\hline BRS Tarumã & $12.54 \mathrm{bA}$ & $11.89 \mathrm{bA}$ & $11.00 \mathrm{bA}$ \\
\hline Average & 13.43 & 12.35 & 10.79 \\
\hline \multirow[t]{2}{*}{ CV (\%) } & & 10.99 & \\
\hline & \multicolumn{3}{|c|}{ Number of grains per spikelet } \\
\hline BRS Figueira & $2.011 \mathrm{abA}$ & $1.794 \mathrm{aA}$ & $1.366 \mathrm{aB}$ \\
\hline BRS Umbu & $2.057 \mathrm{aA}$ & $1.800 \mathrm{aB}$ & $1.362 \mathrm{aC}$ \\
\hline BRS Guatambu & $1.245 \mathrm{bA}$ & $1.237 \mathrm{aA}$ & $1.087 \mathrm{aA}$ \\
\hline BRS Tarumã & $1.775 \mathrm{abA}$ & $1.704 \mathrm{aAB}$ & $1.405 \mathrm{aB}$ \\
\hline Average & 1.772 & 1.634 & 1.305 \\
\hline \multirow[t]{2}{*}{ CV (\%) } & & 20.38 & \\
\hline & \multicolumn{3}{|c|}{ Grain yield $\left(\mathrm{kg} \mathrm{ha}^{-1}\right)$} \\
\hline BRS Figueira & $2067.20 \mathrm{aA}$ & $1429.80 \mathrm{abB}$ & $400.74 b c$ \\
\hline BRS Umbu & $2075.80 \mathrm{aA}$ & $1552.49 \mathrm{aB}$ & 293.65 bC \\
\hline BRS Guatambu & 1096.76 bA & $1040.00 \mathrm{cB}$ & $188.58 \mathrm{bC}$ \\
\hline BRS Tarumã & $1362.15 \mathrm{bA}$ & $1175.25 \mathrm{bcB}$ & $891.44 \mathrm{aC}$ \\
\hline Average & 1650.48 & 1299.38 & 443.60 \\
\hline \multirow[t]{2}{*}{ CV (\%) } & \multicolumn{3}{|c|}{30.43} \\
\hline & \multicolumn{3}{|c|}{ Hectoliter weight $\left(\mathrm{kg} \mathrm{hL}^{-1}\right)$} \\
\hline BRS Figueira & 74.27 bA & $72.13 \mathrm{cB}$ & $68.79 \mathrm{cC}$ \\
\hline BRS Umbu & $77.53 a B$ & $79.43 \mathrm{aA}$ & $71.38 \mathrm{bC}$ \\
\hline BRS Guatambu & 73.33 bB & $76.47 \mathrm{bA}$ & $75.17 \mathrm{aA}$ \\
\hline BRS Tarumã & $74.53 \mathrm{bA}$ & $75.07 \mathrm{bA}$ & $73.93 \mathrm{aA}$ \\
\hline Average & 74.92 & 75.77 & 72.32 \\
\hline CV (\%) & \multicolumn{3}{|c|}{2.31} \\
\hline
\end{tabular}

* Means followed by the same letter, lower case (the column) and capital (in line) do not differ by Duncan test at $5 \%$ probability of error.

capacity to compensate for the lack or excess of a yield component by modifying or adjusting other components (FrEEZE and BACON, 1990). Compensating effects of grain yield components caused by stress sources, such as cuts or grazing, depend on the cultivar, environment and interaction between them (ATCHLEY and ZHU, 1997). In general, late-early cultivars BRS Guatambu and BRS Tarumâ, which have greater tillering capacity than the others, have more spikelets per spi$\mathrm{ke}$, as this yield component is closely related to tiller production, development and survival (DAvidson AND CHEvalier, 1990). However, cultivars with low tillering capacity display greater spikelet fertility (Мотzo et al., 2004), resulting in more grains per spikelet, as observed in this experiment.

Yield components presented significant alterations in grain yield and quality, as confirmed by the variance analysis of the data related to grain yield and hectoliter 
weight. Grain yield and hectoliter weight were not affected by nitrogen fertilization, but they varied significantly in terms of cultivar and cut regime.

The behavior of the cultivars was influenced by the number of cuts, with a significant interaction between these factors. Accordingly, the four dual-purpose wheat cultivars presented significant reductions in grain yield when submitted to one or two cuts, compared to the no-cut regime (Table 2). The BRS Figueira and BRS Umbu cultivars presented higher production in SC and 1C, and a drastically reduction in 2C. According to Wendt et al. (2006), this response is due to the fact that these cultivars have shorter cycles than the others. The same order of yield decline was observed in BRS Guatambu, although it also had a lower yield in the other two regimes. For the BRS Tarumã cultivar, despite the significant yield reduction found in the three regimes, the decline was smaller. BRS Tarumã subjected to $2 \mathrm{C}$ management presented the highest yield, being a consequence of its cycle, i.e. late-early with a longer cycle than the others. As the cuts took place during the same period, the 2C management did not have such a strong effect on BRS Tarumã, which had more time for vegetative re-growth with the reproductive growth occurring after the cuts. This is confirmed by the fact that the harvest duration was the same for all cultivars in the two-cut regime. Scheffer-Basso et al. (2001) concluded that cuts normally reduce grain yield in winter cereals, as observed in this study, due to the plant's limited ability to produce new leaf area quickly after cutting and to avoid tiller senescence during the reproductive period. However, Del Duca et al. (2000), working with the dual-purpose cultivar BRS 176, observed yields of 3,451 kg ha-1, 3,483 $\mathrm{kg} \mathrm{ha}^{-1}$ and 2,104 kg $\mathrm{ha}^{-1}$ in the no-cut, one-cut and two-cut regimes, respectively. For some wheat cultivars, reductions in grain yield may occur after consecutive cuts, as well as decreases in the hectoliter weight $(\mathrm{PH})$ and in the weight of 1,000 seeds. In fact, a considerable quantity of forage can be removed without seriously affecting grain yield in the one-cut regime. On the other hand, this behavior does not reoccur when the two-cut regime is used (BorTolini et al., 2004). According to MARTIN et al. (2010), the grain yield achieved by applying nitrogen at rates of $60 \mathrm{~kg} \mathrm{ha}^{-1}$ at sowing and $60 \mathrm{~kg} \mathrm{ha}^{-1}$ in coverage resulted in yields ranging from 1,211 (Tarumã) to 2,434 $\mathrm{kg} \mathrm{ha}^{-1}$ (Figueira), in the case of blunt cuts in Dois Vizinhos, Paraná.

As shown in table 2, cut regimes did not adversely affect PH in BRS Tarumã and BRS Guatambu, probably because of plant cycle that is longer in these cultivars. There was enough time, even after the second cut, for ample grain development. Because BRS Figueira and BRS Umbu have a shorter cycle, the second cut led to lower grain quality when compared to $\mathrm{PH}$ parameter.

Comparing cultivars within the same crop regime, BRS Umbu presented higher quality in SC and 1C. In 2C treatment BRS Guatambu and BRS Tarumã, which have a longer cycle, featured higher quality confirming that cuts do not influence grain quality in these cultivars, despite lowering production.

According to $\mathrm{PH}$, wheat grains may be classified into three categories (BrasIL, 2001): Type 1, with a minimum $\mathrm{PH}$ of $78 \mathrm{~kg} \mathrm{hL}^{-1}$; Type 2, with a minimum $\mathrm{PH}$ of $75 \mathrm{~kg} \mathrm{hL}^{-1}$; and Type 3, with a minimum $\mathrm{PH}$ of $70 \mathrm{~kg} \mathrm{hL}^{-1}$. As the average $\mathrm{PH}$ in this study was 74.3 , wheat grains did not attain Type 2 classification. Nevertheless, the variation among the cultivars and crop regimes was pronounced. For example, BRS Umbu presented a Type $1 \mathrm{PH}$ in the $1 \mathrm{C}$ regime, and BRS Figueira did not obtain the minimum $\mathrm{PH}$ for Type 3 in $2 \mathrm{C}$ regime.

In general, nitrogen fertilization in wheat crops contributes to increasing yield, as reported by ZAGONEL et al. (2002). However, there was no response to nitrogen fertilization when evaluating yield components, which is corroborated by LoEwy (1990). As an alternative explanation, we may argue that the crop development period was very dry, mainly at the times when cover nitrogen fertilizer was applied. It is known that the soil water deficit has a negative effect on hectoliter weight and grain yield in wheat crops (GUARIENTI et al., 2005). In addition to the low water availability, soil fertility may have contributed to the lack of response to nitrogen fertilization. The experimental area's soil has a mean content of organic matter in the $0-0.2 \mathrm{~m}$ layer of $40.2 \mathrm{~g} \mathrm{dm}^{-3}$. Considering that the soil had been used for no-till farming for more than eight years, it is probable that in the upper layers the amounts of organic matter would be greater than this average value (Matowo et al., 1999; Andreola et al., 2000). An additional factor is the fact that the crop grown in this area before wheat was soybean; this leguminous plant contributes to fixing nitrogen in the soil, raising the organic matter decomposition rate, leading to a low $\mathrm{C}: \mathrm{N}$ ratio and thereby providing $\mathrm{N}$ to succession plants.

\section{CONCLUSION}

The short-cycle or semi-late crops BRS Figueira and BRS Umbu presented a higher grain yield under no-cut or even one-cut regimes. The long-cycle or late-early crops BRS Guatambu and BRS Tarumã did not present reductions in grain quality measured by hectoliter weight, proving to be more adapted to cut regimes. The lack of response to nitrogen dose and application strategies was influenced by the environmental conditions, considering both soil and climate.

\section{ACKNOWLEDGEMENTS}

To Dr. José Pereira (Embrapa Trigo, Brazil) for providing the dual-purpose wheat seeds. 


\section{REFERENCES}

ANDREOLA, F; COSTA, L.M.; OLSZEVSKI, N. Influência da cobertura vegetal de inverno e da adubação orgânica e, ou, mineral sobre as propriedades físicas de uma Terra Roxa Estruturada. Revista Brasileira de Ciência do Solo, v.24, p.857-865, 2000.

ATCHLEY, W.R.; ZHU, J. Developmental quantitative genetics, conditional epigenetic variability and growth in mice. Genetics, v.147, p.765-776, 1997.

BHERING, S.B.; SANTOS, H.G. Mapa de solos do Estado do Paraná: legenda atualizada. Rio de Janeiro: EMBRAPA/IAPAR. 2008. $74 \mathrm{p}$.

BORTOLINI, P.C.; SANDINI, I.; CARVALHO, P.C.F.; MORAES, A. Cereais de inverno submetidos ao corte no sistema de duplo propósito. Revista Brasileira de Zootecnia, v.33, p.45-50, 2004.

BRASIL, Instrução normativa $n^{\circ} 7$, de 15/08/2001. Regulamento técnico de identidade e qualidade do trigo. Ministério da Agricultura, Pecuária e Abastecimento. Diário Oficial da Uniâo, Seçáo 1, $21 / 08 / 2001$

BRASIL, Ministério da Agricultura e Reforma Agrária. Regras para análise de sementes. Brasília: SNDA/DNDV/CLAV, 1992. 365p.

BREDEMEIER, C.; MUNDSTOCK, M.C. Estádios fenológicos do trigo para a adubação nitrogenada em cobertura. Revista Brasileira de Ciência do Solo, v.25, p.317-323, 2001.

CREGAN, P.B.; BERKUM, P. Genetics of nitrogen metabolism and physiological/biochemical selection for increased grain crop productivity. Theoretical and Applied Genetics, v.67, p.97-111, 1984.

DAVIDSON, D.J.; CHEVALIER, P.M. Preanthesis tiller mortality in spring wheat. Crop Science, v.30, p.832-836, 1990.

DEL DUCA, L.J.A.; MOLIN, R.; SANDINI, I. Experimentação de genótipos de trigo para duplo propósito na Paraná, em 1999. Passo Fundo: Embrapa Trigo, 2000. 18p. (Boletim de Pesquisa e Desenvolvimento 6)

DEL DUCA, L.J.A.; GUARIENTE, E.M.; FONTANELI, R.S.; ZANOTTO, D.L. Influência de cortes simulando pastejo na composição química de grãos de cereais de inverno. Revista Pesquisa Agropecuária Brasileira, v.34, p.1607-1614, 1999.

EMPRESA BRASILEIRA DE PESQUISA AGROPECUÁRIA EMBRAPA. Ambiente de software NTIA, versão 4.2.2: manual do usuário - ferramental estatístico. Campinas: Centro Nacional de Pesquisa Tecnológica em Informática para a Agricultura, 1997. 258p.

FONTANELI, R.S. Trigo de duplo-propósito na integração lavourapecuária. Revista Plantio Direto, v.16, p.29-32, 2007.

FREEZE, D.M.; BACON, R.K. Row-spacing and seeding rate effects on wheat yields in the Mid-South. Journal of Production Agriculture, v.3, p.345-348, 1990.

FREITAS, J.G.; CAMARGO, C.E.O.; FERREIRA FILHO, A.W.P.; PETTINELLI JÚNIOR, A. Produtividade e resposta de genótipos de trigo ao nitrogênio. Bragantia, v.53, p.281-290, 1994.
GUARIENTI, E.M.; CIACCO, C.F.; CUNHA, G.R.; DEL DUCA, L.J.A.; CAMARGO, C.M.O. Efeitos da precipitaçáo pluvial, da umidade relativa do ar e de excesso e déficit hídrico do solo no peso do hectolitro, no peso de mil grãos e no rendimento de grãos de trigo. Ciência e Tecnologia dos Alimentos, v.25, p.412-418, 2005.

HENDRICKSON, J. R.; BERDHAL, M. A.; LEIBIG, A.; KARN, J. F. Tiller Persistence of Eight Intermediate Wheatgrass Entries Grazed at Three Morphological Stages. Agronomy Journal, v 97, p.1390-1395, 2005.

KOLCHINSKI, E.M.; SCHUCH, L.O.B. Relações entre a adubação nitrogenada e a qualidade de gráos e de sementes em aveia branca. Ciência Rural, v.34, p.379-383, 2004.

LOEWY, T. Nitrogen fertilizer application on wheat in south western Buenos Ayres Province. II. Response of grain quality. Ciencia del Suelo, v.8, p. 57-65, 1990.

MAACK, R. Geografia física do Estado do Paraná. Curitiba: Banco do Desenvolvimento do Paraná. 1968. 350p.

MARTIN, T.N.; SIMIONATTO, C.C.; BERTONCELLI, P.; ORTIZ, S.; HASTENPFLUG, M.; ZIECH, M.F.; SOARES, A.B. Fitomorfologia e produção de cultivares de trigo duplo propósito em diferentes manejos de corte e densidades de semeadura. Ciência Rural, v.40, p.1695-1701, 2010.

MATOWO, P.R.; PIERZYNSKI, G.M.; WHITNEY, D.; LAMOND, R.E. Soil chemical properties as influenced by tillage and nitrogen source, placement, and rates after 10 years of continuous sorghum. Soil and Tillage Research, v.50, p.11-19, 1999.

MCRAE, F. Crop agronomy and grazing management of winter cereals. New South Wales Agriculture, v.59, p.59-69, 2003.

MOTZO, R.; GIUNTA, F.; DEIDDA, M. Expression of a tiller inhibitor gene in the progenies of interspecific crosses Triticum aestivum L. x T. turgidum subsp. durum. Field Crops Research, v.85, p.15-20, 2004.

SCHEFFER-BASSO, S.M.; FLOSS, E.L.; CECHETTI, D.; BARÉA, K.; BORTOLINI, F; Potencial de Genótipos de Aveia para Duplo Propósito. Revista Brasileira de Agrociência, v.7, p. 22-28, 2001.

USDA. Soil taxonomy: keys to soil taxonomy. 9. Ed. Washington, D.C.: United States Department of Agriculture, Natural Resources Conservation Service, 2003. 82p.

VANTINI, P.P.; RODRIGUES, T.J.D.; CRUZ, M.C.P.; RODRIGUES, L.R.A.; MALHEIROS, E.B. Teores de carboidratod totais não-estruturais do capim-Tanzânia adubado com diferentes doses de nitrogênio. Acta Scientiarum Animal Science, v.27, p. 425432, 2005.

WENDT, W; DEL DUCA, L.J.A.; CAETANO, V.R. Avaliação de cultivares de trigo duplo-propósito, recomendadas para cultivo no Rio Grande do Sul. Passo Fundo: Embrapa Trigo, 2006. 2p. (EMBRAPA, Comunicado Técnico, n. 137)

ZAGONEL, J; VENÂNCIO, W.S.; KUNZ, R.P.; TONAMATI, H. Doses de nitrogênio e densidades de plantas com e sem um regulador de crescimento afetando o trigo, cultivar OR-1. Ciência Rural, v.32, p.25-29, 2002. 